Káplár Attila ${ }^{1}$ - Horánszki Andrea ${ }^{2}$

\title{
A CIMIC válságkezelésének filozófiai megközelítése
}

DOI 10.17047/Hadtud.2021.31.E.218

Tanulmányunkban a civil-katonai együttmüködés szerepének vizsgálatával foglalkozunk, amelyet politikai filozófiai megközelítésben elemzünk. Feltett szándékunk volt a CIMIC államépítési tevékenységének és Platón Állam címủ munkájának az ismertetése. Célunk volt továbbá egy elméleti világ ábrázolása, amelynek idealisztikus képével felvázolhatunk olyan társadalmat, melyben a résztvevők nevelése hozzájárul egy olyan stabil állam meglétéhez, amelyben nem fenyeget a meglévő értékrendszer felbomlása, valamint a katonai erők hatalomátvételi kísérlete. A destabilizálódó társadalmak államépítési képességének elméleti megalapozása képezi tanulmányunk alapját. Azt mutatjuk be, hogyan képesek ezek a társadalmak olyan politikai rendszert kiépíteni, amelyek nem csak üres vázként rövid ideig életképesek, hanem hosszú távon fennálló államot alkotnak. Ennek metódusa a platóni államelméletben a megalapozott nevelési módszereket takarja.

KULCSSZAVAK: Civil-katonai kapcsolatok, Platón, államépítés, válságkezelés

\section{The philosophical approach of CIMIC's crisis management}

In our study, civil-military cooperation is investigated in a political-philosophical view. Our goal was to describe the state building activity of CIMIC and Plato's work, „Politeia”. Additionally, we intended to describe an ideological world, by which a society can be outlined where the education of the participants contribute to the existence of such a state, where the dissolution of the existing value system and the attempt of military takeover is not a threat. The ideological foundation of destabilizing societies' state building ability is the basis of our study. We present that how these societies can build such a political system that is viable not just for a short period of time, but can enbody a state which lasts in the long run. The key to achieve this goal is in the well-founded educational methods of Plato's Theories of State.

KEYWORDS: Civil-military relations, Plato, State building, crisis management

\section{Bevezetö}

Az alábbi tanulmányunkban a civil-katonai kapcsolatok müködését mutatjuk be, illetve megkíséreljük összhangba hozni azzal az antik filozófia nézeteit. Ennek okán két fejezetre osztható az írásunk. Mivel a munkánk során a civil-katonai kapcsolatok és a platóni politikai filozófia közötti párhuzamot vizsgáljuk, az első részben szükséges, a minél pontosabb értelmezéshez a civil-katonai kapcsolatok tevékenységi körének és müködésének alapjait bemutatni. A második részben pedig a Platón által vallott filozófiai elveket vázoljuk fel. Írásunkban kitérünk arra, hogy pontosan miért is választottuk ezt a témát, illetve, hogy miért látjuk úgy, hogy Platón még mind a mai napig tud számunkra olyan gondolati alapként szolgálni, amelyre érdemes odafigyelnünk. Tanulmányunkkal arra akarjuk felhívni a

\footnotetext{
${ }^{1}$ Nemzeti Közszolgálati Egyetem, Hadtudományi Doktori Iskola, doktorandusz - National University of Public Service, PhD Candidate; kaplarat91@gmail.com

${ }^{2}$ Nemzeti Közszolgálati Egyetem, Fejlesztési Igazgatóság, projekt szakmai koordinátor - National University of Public Service; horanszki.andrea.eva@uni-nke.hu
} 
figyelmet, hogy meglátásunk szerint a politikai filozófia és a hadtudomány egymásra reflektál, illetve remek kiegészítőjeként szolgál egyik a másiknak, így alkotva meg egy sajátos nézőpontot, melyben vizsgálódni lehet. Jelen tanulmányunk ezt a fajta gondolatmenetet hivatott bemutatni, amelyben a hadtudományt és a politikai filozófiát ötvöztük.

Tanulmányunkat, témáját illetően, a hadtudományi kutatások nemzetközi válságkezelés és békefenntartás ágához soroljuk. Célunk volt, hogy a destabil régiók stabilizáló eszközeként szolgáló gondolatok tárházát munkánkkal gyarapítsuk. ${ }^{3}$ Ennek értelmében, célunk nem a demokrácia export mikéntjének leírása, hanem egy stabil fenntartható állam platóni gondolati síkon való felépítése. Ezzel összefüggésben vizsgáljuk a civil-katonai kapcsolatok tevékenységét és feladatait, koncentrálva a stabilizációt elősegítő feladatkörökre.

\section{A civil-katonai kapcsolatok müködése, tevékenységi köre}

Az elméleti hátteret tekintve a civil-katonai kapcsolatok lényege, hogy a fegyveres eröknek a számukra felhatalmazást adott civil hatóságokat kell szolgálniuk, ezek céljaihoz kell igazítani tevékenységüket, annak ellenére is, hogy birtokolják azt az erőt, amivel felülkerekedhetnének rajtuk. ${ }^{4}$ A civil-katonai kapcsolatok feladatai, funkciói a NATO AJP 9 számú doktrínájában ${ }^{5}$ kerültek kifejtésre. A CIMIC a katonai akciók komponenseként müködik, tehát attól nem különül el. Funkcióit tekintve a politikai és a katonai műveleti célok végrehajtása során az összes részt vevővel kapcsolatot tart, koordinálja azokat, itt a politikai - katonai és a humanitárius civil szereplöket kell érteni. A koordináció segítségével biztosítja, hogy a műveletben részt vevő elemek összekapcsolódva, együttmüködve legyenek képesek betölteni adott funkcióikat. Ebből kifolyólag mondhatjuk azt, hogy a koordináció folyamata elsődleges fontosságot képvisel a mủvelet egyben tartása szempontjából. Minden müvelet komplex így szükség van az alapelemek együttmüködésére és arra, hogy minden résztvevő ellássa megfelelő szinten a funkcióját, itt a politikai környezetre, a védelmet és biztonságot szolgáltató fegyveres erők és a gyakorlati segítséget nyújtó humanitárius komponensek feladataira gondolunk. A koordináció az erőforrások stratégiailag leghatékonyabb felosztásában is szerepet játszik, pl. a duplikáció megakadályozásában. Azt mondhatjuk, hogy a koordináció minél nagyobb hatékonysággal müködik, annál hatékonyabbá válhat maga a müvelet is. A civil-katonai egységek összességében tehát a parancsnok segítőjeként müködnek. A műveleti területen biztosítják az adott polgári társadalommal, civil és nemzeti szervezetekkel, a kormányzattal történő kommunikációt, együttműködést. A műveleti környezetre telepített fegyveres erők számára kiemelten fontos, hogy a müveleti környezet optimális legyen, támogató jellegüvé váljon. Ezek megléte esetén a parancsnok rendelkezésére állhat a müvelet szempontjából legmegfelelöbb müveleti környezeti morál,

\footnotetext{
${ }^{3}$ Boda 2016.

${ }^{4}$ Feaver 1999, 214.

5 A NATO civil-katonai kapcsolatokra vonatkozó katonai doktrínája, amely tartalmazza a Szövetség katonai erőinek irányító alapelveit, iránymutatást nyújt.
} 
eszközrendszer így segítségükkel a parancsnok kihasználhatja a mindebböl fakadó taktikai elönyöket. ${ }^{6}$

Összefoglalásként elmondható, hogy a civil-katonai együttmüködés mára már elengedhetetlen része a müveletek - föleg a békemüveletek esetében - a müveleti struktúrának. Hiszen szerepe már a müvelet megkezdése elött jelentős, a müveleti környezet megismerése, felmérése és a kapcsolatok felvétele során. Majd a müvelet alatt a koordináció biztosítása és a folyamatos kapcsolattartás a fő funkciói. Koordinációt a müveletben részt vevő egységekkel, a többi civil vagy katonai komponensekkel, a nemzeti hatóságokkal, kormányzattal, a müveleti területen szerepet vállaló nemzetközi szervezetek között szükséges biztosítani.

A kapcsolattartás ugyanezen elemek között szükséges, kiegészülve a polgári civil társadalommal. Mindezek figyelembevételével lehetséges - a gyakorlati feladatok és funkciók, a háttérinformációk ismeretében - bemutatni az elméleti hátteret, melyet politikai filozófiai oldalról kívánunk megközelíteni a következő fejezetben.

\section{Civil-katonai kapcsolatok és a békemüveletek közötti kapcsolat}

A civil-katonai kapcsolatok történelmi kialakulását tekintve az a megállapítás tehető, hogy e terület jelentősége a globalizációval erősödött meg, egyre több szereplöje van a zajló konfliktusoknak. Ennek okán számos aktor között van szükség effektív együttmüködésre, amihez elengedhetetlen a megfelelöen felépített és strukturált kapcsolattartás kialakítása. Ehhez nem elegendő csupán a civilszféra részvétele, itt már megjelennek, mint szükséges követelmények, a fegyveres erők nyújtotta plusz funkciók is. A CIMIC egységek elsődlegesen harctámogató funkcióval rendelkeznek, a megfelelő müveleti környezet kialakításában játszanak többek között fontos szerepet. A civil-katonai együttmüködés, funkcióját tekintve amolyan összekötő kapocsként müködik az adott müveleti környezetben megtalálható nemzeti és helyi hatóságokkal, szervezetekkel, civil szervezetekkel, nemzetközi szervezetekkel és magával a civil társadalommal is kapcsolatot tart fenn. Igyekszik kooperációt kialakítani a müvelet szempontjából jelentős szereplők között. ${ }^{7}$ Véleményünk szerint a civil-katonai együttmüködés a békeműveletek során végzi többoldalú feladatait a teljes spektrumában. ${ }^{8}$ Emiatt tehát szükséges kifejteni mit is takar a békemüvelet fogalma.

A békeműveletek ${ }^{9}$ a komplex vészhelyzetekkel és a gyenge vagy államisággal rendelkező országok jelentette kihívásokkal szemben jönnek létre. Itt tetten érhető az államépítés és a békeműveletek közötti kapcsolat. A békeműveletek során nem csupán katonai erőt alkalmaznak, ezek összetett, komplex missziók, amelyek fegyveres erők mellett,

\footnotetext{
${ }^{6}$ NATO: Chapter 1 The place of CIMIC within NATO operation. In AJP-9. NATO civil-military co-operation (CIMIC) doctrine. 1-16. https://www.nato.int/ims/docu/ajp-9.pdf (Letöltés ideje: 2020. 11. 27.)

${ }^{7}$ Az olvasó számára felmerülhet egyfajta hiányérzet a civil-katonai kapcsolatok feladatkörének és müködésének teljeskörü bemutatásának hiánya okán. Azonban a tanulmányunk terjedelmi korlátjai nem teszik számunkra lehetővé a CIMIC feladatkörének és müködésének teljeskörü bemutatását, így az írásunk szempontja szerinti leglényegesebb feladatkörökre koncentráltunk.

${ }^{8}$ Handerson 2020.

9 A civil megközelítésủ fogalmat alkalmazzuk a katonai használatú béketámogató művelet helyett, mert tanulmányunk témáját tekintve alapvetően civil szemszögből íródott.
} 
diplomáciai és humanitárius szervezetek részvételét is megkövetelik. Alapjukat politikai megállapodások adják, amelyekben a célok is definiálva vannak. A békemüveletek fajtái közé soroljuk a békekikényszerítő, békefenntartó, konfliktus megelőző, béketeremtő, békeépítő és a humanitárius segítségnyújtó missziókat. ${ }^{10} \mathrm{Ez}$ alapján békeműveletnek nevezzük azokat a missziókat, amelyek segítségével a felállított vagy vállalt békeállapot fenntartható marad. Ezen mủveletek során az alapvető nemzetközi jogi szabályozás alapján tiszteletben tartják az emberi jogokat, a békét, a biztonságot, függetlenséget és ezek megőrzésének céljából politikai döntés alapján fegyveres eröket vetnek be. ${ }^{11}$ Összességében azt lehet mondani, hogy a békemüvelet, mint gyüjtőfogalom a béke fenntartására, a béke létrehozására és a béke ösztönzésére irányuló intézkedéseket eszközölő müveletek összességét takarja, melyekben kiemelt szerepe van a civil-katonai együttmüködés effektív voltának. A civil katonai egységek a békeműveletet segíti a rendelkezésre álló eszközökkel és erőkkel. Ezt a feladatát négy tevékenységi kör által látja el: kapcsolattartás, felkészítése, elemzés-értékelés, végrehajtás. A békemüveletek esetében kiemelten fontos a civil-polgári környezet megnyerése, a velük való megfelelő szintű kapcsolattartás. Már a müveletek megkezdése elött kiemelt szempontként jelenik meg a műveleti környezet feltérképezése, megismerése. A misszió eredményességének előfeltétele a stabil müveleti környezet megléte, illetve annak kialakítása. Ez a feladat a civilkatonai kapcsolatokkal foglalkozó szakemberek tevékenységi körébe tartozik. Kulcsfontosságú tényező a polgári és a katonai erők céljainak harmonizálása, a civil testületek tervezésbe való bevonása, a velük történő folyamatos kapcsolattartás. A CIMIC elemzési feladata során vizsgálja a helyi gazdaság helyzetét, a kormányzat és a közigazgatás állapotát, a civil lakosság szükségleteit, civil szervezetek jelenlétét és azok befolyásolási képességének mértékét, a média állapotát. Mindezek elemzése után felállítják az aktuálisan meglévő müveleti környezet állapotának képét. Ezek tudatában hatékonyabban képesek ellátni kapcsolattartói szerepkörüket, illetve növelik a polgári környezet megnyerésének lehetőségét. $^{12}$

A továbbiakban szükséges a civil-katonai kapcsolatok fogalmának békemüveletek során való jelentésének kibontására is, hiszen fogalma más és más értelmet nyer, függően attól, hogy milyen környezetben alkalmazzák. A nyugati katonai közösségben jelentése szerint a civil és katonai szféra közötti koordináció, együttmüködés, információcsere, közös tervezés jelentette feladatokat takarja, melyek a műveletek sikeres végrehajtásához elengedhetetlenek. Napjaink békeműveleteire jellemző a regionális szervezetek erőteljesebb szerepvállalása. Egyre több a belső konfliktus, ahol a szembenálló felek gyakran nehezen azonosíthatók. Új feladatként jelent meg a demokratikus választások segítése, tehát a demokratizálódás folyamatában való segítségnyújtás, az ehhez szükséges intézmények felállításában való közremüködés.

\footnotetext{
10 NATO: Peace Support Operations. AJP-3.4.1 https://info.publicintelligence.net/NATO-PeaceSupport.pdf (Letöltés ideje: 2020. 11. 27.)

${ }^{11}$ Handerson 2020.

12 Bokros 2012, 151-153.
} 
Egyszóval az államépítés elősegítése is a CIMIC feladatkörébe került. ${ }^{13}$ Ezek az új feladatok a civil-katonai együttmüködés szempontjából is jelentősek, hiszen a regionális szervezetekkel való intenzívebb együttmüködés is előtérbe került. Továbbá a demokratizálódás folyamatában történő segédkezés során is nagy hangsúly kerül a civilkatonai összhang megteremtésére, mivel a müvelet sikerének előfeltétele a megfelelő szintü együttmüködési készség megteremtése. Mindezek tudatában tehát kijelenthető, hogy a civilkatonai kapcsolatok szakemberei a békemüveletek során kulcsszerepet játszanak az államépítési feladatokat is magába foglaló tevékenységükben.

\section{A platóni filozófiai háttér}

A politikai filozófiai elméleti háttér bemutatása során az antikfilozófiai gondolkodóra, Platónra fogunk támaszkodni.

Az eddigiek után világosan érzékelhető, hogy mennyire nélkülözhetetlen a civil-katonai kapcsolatok korunk hadikultúrájából. Viszont a CIMIC tevékenysége nem lehet ad hock döntések sorozata. Mindig kell valamilyen irányító mozzanat vagy ideológiai háttér. Természetesen a vasfüggöny utáni Közép - Európában az ideológiai irányító elvek rossz szájízt hagynak maguk után, azonban nem egy szemellenzős dogmákon alapuló ideológiai vezérelvre akarunk itt utalni. A politikaelméleten belül a politikai filozófiának és az államépítésnek gazdag szakirodalma van, amelyek mindegyike remek kiindulási alapot biztosítanak arra, hogy megtaláljuk azt a vezérelvet, amelyek segíthetik a katonákat abban, hogy egy komplex és nehezen értelmezhető helyzetben jó döntéseket tudjanak hozni, kiélezett helyzetek közepette. Megítélésünk szerint ez a két tudományág - értjük ezalatt a hadtudományt és a politikatudományt - nem állnak egymástól olyan messze, mint azt első ránézésre gondolnánk. Ennek bizonyítása végett a már korábban vázolt CIMIC feladatok mellett bemutatjuk egy általunk vizsgált ókori filozófus államelméleti felfogását és igyekszünk felvázolni, hogy mennyire lehet ezt a kettőt összhangban kezelni. A civil-katonai kapcsolatok elméletének alapkérdése az, hogyan ellenőrzi egy adott polgári kormány a felügyelete alá rendelt katonai erőt. Örök kérdés, hogy mekkora erőforrást kell biztosítani a hadsereg számára, ugyanis elég erősnek kell lennie ahhoz, hogy védelmet biztosítson, azonban nem kerekedhet felül a politikai hatalmon. A kormányzás egyik alap problémájából lehet levezetni. A kormányzatot elég hatalommal kell felruházni ahhoz, hogy megvédje a társadalmat, de nem elég hatalommal ahhoz, hogy zsarnokká válhasson. Ez egy alap problémája a demokráciáknak. ${ }^{14}$ A történelemben természetesen nem új keletü, hogy az erős katonai hatalom átveszi a politikai hatalmat is az országban. Láthattunk ilyen történést Afrikában Zimbabwe esetében 2017-ben is. ${ }^{15}$ Ez azonban nem elszeparált eset, 2012 - 2020 között több katonai hatalomátvétel is történt a világban, amelyek remekül tudják illusztrálni a

\footnotetext{
${ }^{13}$ Boldizsár Gábor: A béketámogató műveletek kialakulása, fejlődése, helye a katonai müveletek rendszerében. Előadások. $5-6$. http://m.ludita.uninke.hu/repozitorium/bitstream/handle/11410/1053/nek 2001_2 boldizsar.pdf?sequence=1\&is Allowed=y (Letöltés ideje: 2020. 11. 23.)

14 Feaver 1999.

15 Mackintosh 2017.
} 
CIMIC szükségességét, a teljesség igénye nélkül, itt ki lehet emelni: Burkina Faso, Thaiföld, Egyiptom, Közép-Afrikai Köztársaság, Pápua Új-Guinea esetét. ${ }^{16}$

A tanulmány további részében azt kívánjuk alátámasztani, hogy a mai modern korban is van elméleti alapja és létjogosultága az antikfilozófiai gondolkodásnak, illetve magának a politikai filozófiának, hiszen ezek ismeretében képesek lehetünk egy olyan elméleti keretet létrehozni, mely segítségével könnyebben felépíthetünk egy olyan morális egységközösséget, amelynek kereteiben a CIMIC a jövőben operálni tud, és még hatékonyabbá válhat segítségével a békemüveletek tevékenységi köre.

Az elméleti vizsgálódásnak az alanyaként Platónt választottuk. Ennek két oka van. Az első merőben egyszerü, a kronológia. A platóni dialógusok egyik központi figurája Szókratész alakja, akit szokás az antik görög filozófusok közül kiemelten kezelni, tekintettel megkerülhetetlen szerepkörére. Ennek okán majdhogynem a dokumentált filozófiai gondolatok forrásáig mehetünk vissza a következő fejtegetésekben. A másik ok az, hogy a platóni filozófia esszenciális gondolata az ideák világa. Ebből adódóan pedig az ember által annyira vágyott tökéletesség elméleti gondolatkörét tudjuk górcső alá venni.

\section{Az antik filozófia vizsgálatának az oka}

A fentebb leírtakkal szándékunkban állt bemutatni, hogy a civil-katonai kapcsolatok mennyire nélkülözhetetlenek a mai modern katonai szerepvállalások szempontjából. Viszont felmerülhet a kérdés, hogy milyen filozófiát milyen elméleti iránymutatást érdemes szem előtt tartani abban az esetben, hogy ha egy polgári társadalom, politikai, karhatalmi, illetve civil hármasságát próbáljuk olyan összhangba hozni, amely lehetővé teszi a megfelelő társadalmi rendet és stabilitást. Ez elengedhetetlenül fontos abban az esetben, ha a katonai müveletek olyan konfliktusokat eredményeznek, amelyek annyira jellemzik a mai KözelKelet térségét.

A nemzetközi diskurzusban napjainkban is megjelenik hivatkozási alapként az antik görög filozófia a civil-katonai kapcsolatok elméleti vizsgálódásai során. Itt megemlíthetjük Jim Golby és Hugh Liebert szerzőpáros nem rég megjelent Keeping Norms Normal: Ancient Perspectives on Norms in Civil-Military Relations ${ }^{17}$ címü tanulmányát. Írásukban az antik görög filozófiai gondolatokra támaszkodva építik fel az elméletüket.

Magyar nyelven kevésbé kutatott a filozófia és a civil-katonai kapcsolatok elméletének párhuzamba állítása. Tanulmányunk további részében arra fogunk rávilágítani, hogy milyen szinten lehet használni a filozófiát ilyen kérdésekben. Azonban, itt mindenképp le kell szögezni, hogy nem lehet egy széles spektrumú, filozófiai vizsgálódást végezni, mindenképp egy részletes elméleti keretrendszer felépítése szükséges, amely egy adott szempontra világít rá.

\footnotetext{
16 ria.ru: Военные перевороты в https://ria.ru/20200818/1575945538.html?fbclid=IwAR1EWR-IXQ61AAqnxnMAfn6uCmlIlAEltcZ1fONR_iJ9wTtjheqZ3XqT4Q (Letöltés ideje: 2020. 11. 22.)

${ }^{17}$ Golby, Liebert 2021.
} 
Ezt azért tartjuk fontosnak, mivel rendkívül sok irányvonal és szinte feldolgozhatatlan mennyiségü irodalom áll a rendelkezésünkre. Ha nem akarjuk elveszíteni tanulmányunk fókuszát, akkor muszáj ilyen megkötést tennünk.

Tanulmányunkban Platón Állam című müvét kívánjuk elemezni, amiben Platón felvázolja, mi alapján épül fel az állam és miért van rá egyáltalán szükség. A következökben igyekszünk logikailag strukturált formában bemutatni az ideális platóni rendszert. Azt fontos kiemelni azonban, hogy itt egy ideál állapotról lesz szó, amely, mint olyan, természetesen nem megvalósítható. Azonban, lényege is pont ebben rejlik, hiszen az ideális állapot fennállása esetén mutatja be, hogyan is müködne az tökéletesen. ${ }^{18}$

\section{A platóni filozófia}

Platón elméleti megközelítéseinek középpontjában az az elgondolás vehető észre miszerint a vizsgálódások során ki kell találni, hogy mit értünk egy-egy fogalom alatt és hogy mitől lesz az, ami. Ez különösen fontos akkor, amikor olyan szavakat vagy kifejezéseket használunk, mint a morál vagy az igazságosság. Ennek a megközelítésnek az alapja egy kommün idea megléte. Ez az, ami lehetővé teszi a köz számára, hogy mindenki tökéletesen tudatában legyen annak, hogy mi az, amit a fizikai valóban érzékel. Vagyis - értelmezésünk szerint elmondható, hogy az idea az nem más, mint a tökéletesség szakrális tere. A fizikai valóság ennek az ideának mindössze a tökéletlen leképződése, amelyet Platón máig népszerü barlanghasonlatával ${ }^{19}$ igyekszik számunkra értelmezhető formába önteni. Az érzékelés kettőségét a test kettősége kapcsán is könnyen megérthetjük, mivel az ember maga is két részből tevődik össze: a fizikai valója, vagyis maga az emberi test, amely a fizikai valóság érzékeléséhez szükséges, valamint a lelke, amely egyedüliként képes kapcsolódni az ideákhoz. Ennek az oka, hogy az emberi lélek a földi létet megelőző időkben is az ideák világában élt. Ez a forrása annak, hogy képes a tökéletlen felismerésére. Vagyis az ember minden tudása, aminek már birtokában van, volt, vagy éppenséggel lesz, nem más a platóni értelmezésben, mint visszaemlékezés. Vagyis a tudás megszerzésének nem csak a megfigyelés az egyedüli eszköze, hanem az emlékezet használata is fontos. A filozófus feladatköre is itt jön képbe, hiszen az ő feladata, hogy ráleljen az ideális formákra, valamint az ideákra. ${ }^{20}$

A korai műveiben Platónnak három fő állítása van, a már föntebb is taglalt tudás visszaemlékezése, amely szerint a lélek örökkévaló és létezését tekintve is elörébb való, mint

\footnotetext{
${ }_{18}$ Britannica Hungarica Kisenciklopédia - Filozófia. 2016, 242-248. Jelenlegi munkánk magyar nyelven hiánypótló. Ennek értelmében tetszés szerint élhettünk volna a gondolkodásunkat formáló filozófusok bármelyikével, azonban mi mégis Platónt választottuk. Írásunk további részében két okot fogunk erre konkrétan megjelölni. Azonban nem elhanyagolható a kritika, hogy az államépítés gondolatkörét mások is körbejárták már. Elöljáróban szeretnénk lefektetni azt az állítást, miszerint az írásunk a tudományos diskurzus keretei között kíván maradni, amely így kellő szabadságot élvez a gyakorlati alkalmazás adta problémák láncaitól. A platóni dialógusok idealisztikus szemlélete, valamint a nemzetközi diskurzus ezzel kapcsolatos újkeletú vizsgálódásai inspiráltak bennünket arra, hogy miért épp a filozófiatörténet egyik legalapvetőbb gondolkodójához nyúljunk vissza.

${ }^{19}$ Platón ideaelméletét szemlélteti. A barlanghasonlattal célja, hogy megmutassa miből áll az ember számára a megismerés lehetősége. Az emberek nem magukat a dolgokat csak az árnyékukat látják. Az érzékszervekkel tapasztalható dolgok csak tökéletlen árnyképei azoknak, amiket gondolunk.

${ }^{20}$ Szöllős 2019, 52-55.
} 
az emberi porhüvely. A második állítása, hogy az emberi lélek három részre osztható: ezek az értelem, a vágy és a szellem. Annak érdekében, hogy az ember harmóniában élhessen, az értelemnek kell dominálnia a másik két rész fölött. Végezetül pedig említést kell tennünk a már föntebb kifejtett lélek hármas tagolásáról, amely kapcsán ki kell emelni, hogy ideák világának csúcsára a ,jó” ideáját teszi Platón. ${ }^{21}$

\section{A platóni filozófia értelmezése az ideális állam felépítéséröl}

Filozófiai vizsgálódásunk során legelőször az állam létrejöttét kell áttekintenünk. Platónnál az állam keletkezésének egyértelmü oka az ember szükségleteinek megléte, ennek hatására az emberek társulnak egymással, így segítve egymást a szükséges dolgok megszerzésében. Ebből kifolyólag tehát az állam, az emberek szükségleteinek kielégítése céljából való társulását jelenti. Az államot alkotók speciális szerepek szerint társulnak, specializálják magukat olyan foglalkozásokra, melyek egy másik ember szükségleteit elégítik ki. Így kölcsönösen egymásra támaszkodhatnak az egyének. Mivel mindenki csak egyfajta foglalkozást üz, emiatt több egyén társul egymással, ezen okból kifolyólag mondhatjuk, hogy az állam emberek sokaságából áll össze. Minden foglalkozást több ember űz, mivel szükséges a többlettermelés, hogy a saját állam által elő nem teremthető javakat, erőforrásokat egy másik államtól a többlettermékekkel elcserélhessen. ${ }^{22}$

Platón az államot a lélek analógiájára támaszkodva mutatja be. Fontos kérdés, hogy mi az állam célja, és hogy miért jön létre. Erre a kérdésre Platón azt a választ adja, hogy az emberek közötti igazságosság megteremtése a célja az államnak - a már említett szükségletek fizikai kielégítése mellett, így tehát van egy mögöttes transzcendens célja is az állam keletkezésének.

A lélek analógiáját követve három társadalmi osztályt mutat be, mint egy-egy lélekrész. Itt kiemelendő, hogy minden egyes osztálynak, csakúgy, mint a lélekrészeknek megvan a maga feladata, funkciója. A három osztályt a bölcsek, az örök és a munkások képezik. A platóni elgondolás szerint a rétegek között lehetséges az átjárás. Platón számára az ideális államban minden egyes egyénnek megvan a saját szerepe, mellyel az államot szolgálja és így nyer létjogosultságot az egyén létezése. Minden csoportnak megvan a maga erőssége, melyet kihasználva részt vállal az állam rendszerének müködésében. Ahogy azt már említettük ezen lélekrészek alapján ismerteti az állam erényeit és mondhatjuk úgy, hogy az általa ideálisnak vélt társadalmi rétegeket is. Az első ilyen réteg a bölcsek - mint az értelem lélekrésze. A bölcsek fö erőssége az értelem, a bölcsesség megléte. Az őrök, mint a lélek érző részei jelennek meg, kiknek erőssége a bátorság. A harmadik lélek a vágyakozó, ennek szerepét a munkások töltik be. Az ő erényük a mértékletesség. Ezen társadalmi rétegek viselkedése kapcsán a primer befolyásoló tényező az állam. Az állam feladata a társadalom nevelése. A nevelés által lehet „kiképezni” az állam számára legideálisabb vezetőket. Akikkel kapcsolatban elmondható, hogy azok a jó vezetők, akik elvek alapján irányítanak és nem ösztöneik által vannak vezérelve, hiszen így maradhatnak meg az igazság ösvényén. Emellett, az állam felépítésének szempontjából fontos beszélni arról, hogy Platón szerint miért

\footnotetext{
${ }^{21}$ Britannica Hungarica Kisenciklopédia - Filozófia. 2016, 242-248.

${ }^{22}$ Platón 2008, 369c-371b szakasz, 65-68.
} 
szükséges egy állam müködésébe a törvények beiktatása. Platón az Állam címü munkája második könyvének 359a szakaszában tér ki arra, hogy mi is a törvények szerepe, melyek azok a szempontok, amelyek miatt nélkülözhetetlenek az állam életéből. Érvelésének fö pontja az igazságosságból táplálkozik. Állításai szerint az igazságtalanság elszenvedése rossz érzés, azonban igazságosnak lenni jót tesz a léleknek. Ebből kifolyólag az emberek, a társadalom tagjai rájönnek arra, hogy sokkal jobb igazságosnak lenni, így megállapodnak egymással és olyan szabályokat kezdenek el alkotni, melyeket igazságosnak látnak, és melyekből végül összeáll az az állam törvényeinek rendszere. Továbbá az állam alapjait képezi a hadsereg megléte. Lényeges az állam területének védelme, amelyhez megfelelő hadsereg kell - ez képezi az állam egyik alapját, amihez pedig az őrök csoportjai szükségesek. Az örök feladata kulcsfontosságú, így a nevelésük hatékonyságára nagy hangsúlyt kell fektetni. $^{23}$

\section{A hadsereg platóni képe}

Igazságosság kapcsán beszélhetünk egy ember, vagy egy közösség vonatkozásában. Platón munkájában az utóbbira koncentrálunk, mivel annak vizsgálata véleményünk szerint egyszerübb. Ennek okán államba szerveződik, melyben az egyes tevekénységeket mesterségekre osztva biztosítják egymásnak az életfeltételekhez elengedhetetlen eszközöket. Ha az államban az egyének nem elégszenek meg azzal a forrással, amelyet a meglévő államuk biztosítani tud, akkor több földterületre van szükségük, amely szükséglet életre hív egy másik mesterséget, az őrök osztályát, akiket katonákként is tudunk értelmezni. Ezek azok az őrök, akiknek a társadalommal szemben a lehető leglojálisabbnak és segítőkészebbnek kell lenniük, de mindenképp meg kell védeniük őket a külső fenyegetésektől. A platóni világkép értelmében az őrök ilyen fokú beállítottságát csakis a neveléssel lehet elérni, amelyet két módszerrel szükséges erősíteni: testedzéssel és történetek mesélésével. ${ }^{24}$

Ennek értelmében a nevelőknek csak olyan mesét lehet mondani a fiatalok számára, amelyek építik a gyerek jellemét. Szakács Péter elemzésében külön ki is hangsúlyozza Platón azon meglepő állítását, miszerint ki kell tiltani Homéroszt és Hésziodoszt a mesélt történetek közül, mivel arról számolnak be müveikben, hogy az istenek is tesznek rossz dolgokat, holott nekik tökéletesnek kellene lenniük. A platóni gondolatvilágban minden olyan történetet száműzni kell a történetek közül, amelyekben a gonosz győz, illetve a jó szenved. Az őröknek mindig a pozitív karakterhez kell idomulniuk, azokat kell magasztalniuk. ${ }^{25}$

\section{A vezetök}

Platón filozófiája kapcsán, ahogyan már korábban is említettük, az állandó igazságot keresi, az „ideális jót”, azonban ezt sokan keverik össze a múló igazságossággal. Platón filozófiai aktualitásának az alapja éppen itt érhető tetten. Egyes válságövezetekben, ahol a társadalmi feszültségek az egymással szemben álló törésvonalak mentén a pattanásig feszültek, a

\footnotetext{
${ }^{23}$ Széplábi 2009, 8-16.

${ }^{24}$ Platón összes müve. 1984, 5-711.

${ }^{25}$ Szakács 2020, 3-12.
} 
legfőbb/legjobb igazságtétel tevésének a megkísérlése a legjobb, amit ilyen esetekben tenni lehet. Itt el is jutunk egy alapvető kérdésig, mégpedig, hogy kinél legyen a politikai hatalom? Platón az Állam-ban kifejti abbéli vélekedését, hogy erre a legkevésbé sem alkalmas mindenki. Aki erre alkalmas az ritka kivétel, de azt külön kihangsúlyozza, hogy a legkevésbé sem alkalmas erre a névtelen és arctalan tömeg. ${ }^{26}$

Habár megvan a kísértés arra, hogy egy ilyen jellegü gondolat után a ma uralkodó demokratikus keretek közepette a szabadpiac uralta globalizált világban egy ennyire elitista és kirekesztő elgondolást azonnal félredobjunk, megítélésünk szerint, csak a sorok között olvasva kell azt értelmezni. Platón itt azt emeli ki, hogy a démosz nem alkalmas a politikai vezetésre, mert az megfelelő szakképzettséget igényel, illetve olyan komoly jellembeli tulajdonságokat, amelyeket csak a legritkább emberi tulajdonságokként szoktunk számon tartani.

Ennek tudatában tovább is menve, a tömeg szerepe a platóni értelmezés szerint nem más, mint hogy felismerje a jó vezetőt és ha megtalálta, akkor vesse alá magát az akaratának. Ennek az alapja abból a már megtárgyalt elméleti elgondolásból származik, hogy az ideális állam, csak egy ideális vezető által képzelhető el.

Ez pedig a platóni felfogás szerint a „filozófuskirály” személyében valósulhat meg. Ha létezne egy ilyen állami vezető, akkor a törvények csupán akadályt jelentenének a számára. Mivel ilyen a fizikai világban nem lehetséges, még a filozófuskirály személyében sem, ennek okán a törvények segítségével kell kormányozni. Ennek tükrében tehát elmondható, hogy egy a platóni ideák világában lévő államban a tökéletes erkölcsű vezető irányít, ahol az uralkodó szelleme kiterjed az állam szellemére, ahol ennek okán létrejön az alkotmányt éltető szellem, amelyben az erények összessége van jelen. ${ }^{27}$

Ez az az ok, amiért Platón elveti a nyers tömeg uralmat. A tömeg, képtelen egy olyan összetett és komoly felkészülést követelő munka elvégzésére, mint a jó kormányzás. Természetesen itt továbbra is az ideákra vonatkozó elméleti konstrukciókról beszélünk. Az igazságosság tehát az a tulajdonság, mely a tökéletes állam legkomolyabb jellemzője.

\section{Összegzés}

Láthattuk tehát, hogy Platón az ideális államot egy, a legapróbb részletekig kontrollált társadalomban látta, amelynek minden tagját szigorúan irányított neveléssel terelt az állam a megfelelő irányba. Ez a nevelés az, amely vezetővé tette a vezetőt és katonává a katonát. A civil társadalom - a munkások osztálya - egy ilyen ideális államban teljes mértékben biztonságban érezheti magát a hatalmi visszaélésekkel és a karhatalmi erőszakkal szemben. A fentebbi gondolatkörünk üzenetének a rövid konklúziója tehát így hangozhat: a civil-katonai kapcsolatoknak nagy hangsúlyt kell fektetnie arra, hogy tevékenységük során az általuk képviselt eszméket mélyebben megismertessék és átadják a társadalomnak. Az egyes válságövezetekben is, amikor külső segítséggel demokrácia exportot hajtanak végre az adott országban, többet kell tenni, mintsem az üres intézményrendszer receptjét átadva kontrollálják

\footnotetext{
${ }^{26}$ Takács 2016, 41-52.

${ }^{27}$ Takács 2016, 41-52.
} 
az eseményeket. Annak értékeit és jelentését meg kell értetni és meg kell szerettetni a társadalommal, hogy az magáénak érezze. Ha ez megtörténik, akkor egy stabilabb rendszer jöhet létre. A politikai éra mellett a katonai közegre is ugyanez érvényes. A katonai erkölcs és moralitás szintúgy egy olyan dolog, amelyet meg kell ismertetni a katonákkal, hogy lojalitásuk és hazaszeretetük megkérdőjelezhetetlenné váljon hazájuk és a civil polgárság irányába.

Ennek értelmében elmondható, hogy egy így nevelt osztály, mint amilyen a platóni örök osztálya egy ideális államrendben érdektelen kérdés, hogy mekkora hatalommal van felruházva. Maga a gondolat is idegen lenne tőlük, hogy bármilyen formában destabilizálják az állami rendet, ahogy a politikai döntéshozók számára is a fó cél az állam megfelelő müködtetése volna az ideális jó mintáját követve.

\section{FELHASZNÁLT IRODALOM}

Boda József, - Boldizsár Gábor, - Kovács László, - Orosz Zoltán, - Padányi József József,Resperger István, - Szenes Zoltán 2016. A hadtudományi kutatási irányok, prioritások és témakörök. Államtudományi Mühelytanulmányok 36 (2016). https://nkerepo.uninke.hu/xmlui/bitstream/handle/123456789/7247/2016_-evi-16_-szam-a-hadtudomanyikutatasi-iranyok_-prioritasok-es-temakorok-2.original.pdf?sequence $=1$ (Letöltés ideje: 2021. 01. 11.)

Bokros Tünde Ibolya 2012. A civil-katonai együttműködés jelene a béketámogató műveletek alakulásának tükrében. Hadtudományi Szemle 5. (2): 149-157.

http://epa.oszk.hu/02400/02463/00013/pdf/EPA02463_hadtudomanyi_szemle_2012_34_149-157.pdf (Letöltés ideje: 2020. 11. 23.)

Boldizsár Gábor 2001. A béketámogató mủveletek kialakulása, fejlődése, helye a katonai müveletek rendszerében. Elöadások. http://m.ludita.uninke.hu/repozitorium/bitstream/handle/11410/1053/nek_2001_2_boldizsar.pdf?sequence=

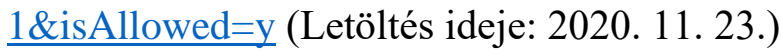

Feaver, Peter D. 1999. Civil-military relations. Annual Review of Political Science 1999. (június): 211-241.

https://www.annualreviews.org/doi/pdf/10.1146/annurev.polisci.2.1.211 (Letöltés ideje: 2020. 11. 24.)

https://doi.org/10.1146/annurev.polisci.2.1.211

Golby, Jim; Liebert, Hugh 2021. Keeping Norms Normal: Ancient Perspectives on Norms in Civil-Military Relations. Texas National Security Review. Vol 44, Iss (2): 75-96. Spring https://tnsr.org/2021/04/keeping-norms-normal-ancient-perspectives-on-norms-in-civilmilitary-relations/ (Letöltés: 2020. 11.20.)

Handerson, Ian 2020. Key CIMIC concepts \& principles. Accord 11 feb. 2020. https://www.accord.org.za/lessons/key-cimic-concepts-principles/ (Letöltés ideje: 2020. 11. 22.) 
Mackintosh, Eliza 2017. Zimbabwe's military takeover was the world's strangest coup.

November 21, 2017. CNN. https://edition.cnn.com/2017/11/20/africa/zimbabwemilitary-takeover-strangest-

coup/index.html?fbclid=IwAR0IcPLsfqxWuiVD2v50C9QBLMjDQpyEzGyZB_c388Hh VJ5Fz04x5USuzh0 (Letöltés ideje: 2020. 11. 22.)

Britannica Hungarica Kisenciklopédia - Filozófia 2016. Szerk. Nádori Attila. Budapest: Kossuth Kiadó.

Platón 2008. Állam. Budapest: Cartaphilus Könyvkiadó.

Platón összes müve. 1984. Budapest: Európa Könyvkiadó.

Szakács Péter 2010. Az igazságosság problémája, Platón utópiájában. Kolozsvár: BabeşBolyai Tudományegyetem (XIII. Erdélyi Tudományos Diákköri Konferencia) 3-12. http://www.etdk.adatbank.ro/pdf/tort_szakacs.pdf (Letöltés ideje: 2020.11.20.)

Széplábi Judit 2009. Platón Politea (Az Állam). Eduline 8-16. http://eduline.hu/segedanyagtalalatok/266-Platon_POLITEIA_Az_all (Letöltés ideje: 2020. 11. 28.)

Szőllős Péter (szerk.) 2019. A filozófia nagykönyve. Budapest: HVG Könyvek, 2019.

Takács Péter (szerk.) 2016. Somló Bódog az államról és az állambölcseletről. Somló Bódog írásai és hátrahagyott jegyzetei egy megírni tervezett Állambölcseletből. In:

Állambölcseleti töredékek. Budapest: Gondolat Kiadó, 2016.

\section{INTERNETES FORRÁSOK}

NATO: Chapter 1 The place of CIMIC within NATO operation. In AJP - 9. NATO civilmilitary co-operation (CIMIC) doctrine. https://www.nato.int/ims/docu/ajp-9.pdf (Letöltés ideje: 2020. 11. 27.)

NATO: Peace Support Operations. AJP - 3.4.1 https://info.publicintelligence.net/NATOPeaceSupport.pdf (Letöltés ideje: 2020. 11. 27.)

ria.ru: Военные перевороты в мире в 2012-2020 годах. ria.ru. https://ria.ru/20200818/1575945538.html?fbclid=IwAR1EWRIXQ61AAqnxnMAfn6uCmlIlAEltcZ1fONR_i-J9wTtjheqZ3XqT4Q (Letöltés ideje: 2020.11.22.) 